\title{
Mononuclear Cell Interstitial Inflammation Assessment
}

National Cancer Institute

\section{Source}

National Cancer Institute. Mononuclear Cell Interstitial Inflammation Assessment. NCI Thesaurus. Code C135469.

An evaluation of the presence or degree of mononuclear cell interstitial inflammation present in a sample. 